\title{
Morphological and reproductive differences among three charophyte species in response to variation in water depth
}

\author{
Heyun Wang ${ }^{1,2}$, Chunhua Liu' ${ }^{1}$, Dan Yu' ${ }^{1, *}$ \\ ${ }^{1}$ Freshwater National Observation and Research Station of Lake Ecosystem in Liangzi Lake, College of Life Sciences, \\ Wuhan University, Wuhan 430072, PR China \\ ${ }^{2}$ Key Laboratory of Ecological Remediation for Lakes \& Rivers and Algal Utilization of Hubei Province, \\ College of Resource and Environmental Engineering, Department of Light Industry, Hubei University of Technology, \\ Wuhan 430068, PR China
}

\begin{abstract}
Some charophyte species reproduce sexually by oospores and vegetatively by bulbils, and the proportion of branch whorls that contain reproductive organs can be used as quantitative measures of the degree of sexual reproduction. We examined inter-specific differences in the proportion of bulbils (PB) by total weight and the proportion of branch whorls containing gametangia (PG) or oospores (PO), as well as morphological and physiological differences among 3 charophyte species (Chara vulgaris Linnaeus, Chara braunii Gmelin, and Nitella gracilens Morioka) responding to variation in water depth $(0.5,1,1.5,2$, and $3 \mathrm{~m})$ in an outdoor experiment. A 2-way ANOVA contrasting species and water depth revealed that shoot elongation and the chlorophyll $a$ to carotenoid (chl a/caro) ratio were primarily affected by water depth. However, variation among species contributed more than water depth to the differences in weight, sexual reproduction ( $\mathrm{PG}$ and $\mathrm{PO}$ ), and the $\mathrm{chl} a / \mathrm{chl} b$ ratio. Additionally, variation among species contributed almost equally to the differences in PB that occurred among different water depths. Both Chara species extended their shoots and increased their PB in response to increasing water depth (from 0.5 to $1.5 \mathrm{~m}$ ). However, deeper water $(2$ and $3 \mathrm{~m}$ ) led to elongated shoots as well as decreased PB, PG, and PO. For N. gracilens, elongated shoots with increased water depth (from 0.5 to $3 \mathrm{~m}$ ) occurred at the expense of both vegetative (decreased $\mathrm{PB}$ ) and sexual reproduction (reduced PG and PO).
\end{abstract}

KEY WORDS: Charophyte · Depth · Inter-specific difference - Sexual reproduction · Bulbils · Macrophytes

\section{INTRODUCTION}

Light is a critical factor for charophyte growth and reproduction (Spence \& Chrystal 1970, Spence 1976, 1982, Stross et al. 1988, 1995). Charophytes are bottom dwellers (Chambers \& Kalff 1987a,b) and the responses of their stems to low light and high water levels have been well documented in previous studies. For example, charophytes can morphologically adapt to either high water levels or low light availability by elongating their stems toward the water surface (Andrews et

${ }^{*}$ Corresponding author: lakeyd@163.com al. 1984a, Casanova 1994, Casanova \& Brock 1999a, Blindow \& Schütte 2007, Wang et al. 2008). Conversely, acclimation of charophytes to low water levels or high light intensity can result in stunted stems, impacted apices, and increased branchlet growth toward the apex as a way to protect the gametangia (Schneider et al. 2006, Wang et al. 2008, Schneider et al. 2015). Charophytes can also photosynthetically acclimate to different amounts of light by regulating pigment content and pattern (Andrews et al. 1984b, Czeczuga 1986, Howard-Williams et al.

() The authors 2015. Open Access under Creative Commons by Attribution Licence. Use, distribution and reproduction are unrestricted. Authors and original publication must be credited. 
1995, Schagerl \& Pichler 2000, Küster et al. 2000, 2004, 2005, Wang et al. 2008).

Charophytes can change reproductive behavior to adjust to fluctuating water levels. For example, the occurrence of sexual reproduction and maturation of oospores are stimulated by decreased water level (Casanova 1994, Casanova \& Brock 1999a, Asaeda et al. 2007) and increased light intensity (Wang et al. 2008). For some charophyte species with bulbils (vegetative, starch-rich organs), the proportion of bulbils (PB) by total dry weight depends on water depth (Casanova 1994) and light intensity, including light used for photosynthesis and traits that are related to photo-inhibition for protection from ultraviolet (UV) radiation (de Bakker et al. 2001).

The growth responses of macrophyte plants in relation to varying water levels have been well demonstrated by previous research, including field investigations (e.g. Schwarz et al. 1996, 2002, Asaeda et al. 2007) and controlled experiments (e.g. Coops et al. 1996, Steinman et al. 2002, Xiao et al. 2006, Deegan et al. 2007, Yu \& Yu 2009). However, most studies that have investigated the responses of charophytes to variation in water depth were carried out in field experiments (e.g. Schwarz \& Hawes 1997, Schwarz et al. 1996, 2002). The inhibition of colonization of deep-water charophyte species, such as Chara corallina Willdenow and C. fibrosa Bruzelius, that grow at depths >15 m (Schwarz \& Hawes 1997), has often been explained by photo-inhibition at low photosynthetic photon flux density (PPFD) (Schwarz et al. 1996). In contrast, some charophyte species that grow in shallow water suffer growth depression from high light intensity or UV-B radiation (Vieira \& Necchi 2003, de Bakker et al. 2001, Asaeda et al. 2007). Therefore, studies that compare the response of different charophyte species to variation in depth gradients from shallow to deep water are very important and can explain the acclimation of charophytes to water depth.

Assemblages of charophyte species in lakes frequently vary in abundance with depth, and speciesspecific zonation within the water column is reflected by the availability of underwater light (Schwarz et al. 1996, 2002) and can be explained by inter-specific differences in photosynthetic responses and intracellular partitioning patterns of newly fixed organic carbon in response to light (Sorrell et al. 2001). We therefore hypothesize that, due to different light demands, single charophyte species differ in their response to water depth.

For 3 charophyte species, we aimed to predict which parameters would be influenced mainly by depth and which would be more likely to vary among species in an experiment with a controlled gradient in water depth. We chose 3 charophyte species that are frequently found in Liangzi Lake, China (2 Chara species and 1 Nitella species), to conduct a field survey of depth distributions as well as a controlled experiment to investigate how water depth affects interspecies differences in morphology, pigment pattern, and reproduction. To address this aim, we tested the following hypotheses: (1) plants respond to an increase in water depth by elongating shoots, and water depth will contribute more to shoot elongation than variation among species, (2) plants respond to an increase of water depth by reduced sexual reproduction, with variation among species contributing more to variation in sexual reproduction than variation among depths, and (3) plants exhibit different allocation patterns of resources along depth gradients.

Charophyte species reproduce sexually by oospores and vegetatively by bulbils (Bonis \& Grillas 2002). In the present study, the proportions of branch whorls containing gametangia (PG) or oospores (PO) out of the total number of branch whorls were considered as the quantitative measurements of sexual reproduction.

\section{MATERIALS AND METHODS}

\section{Field investigation and plant materials}

Liangzi Lake is a shallow lake located on the central reaches of the Yangtze River, and lies in a subtropical region with seasonal fluctuations in water levels ranging from 0.5 to $2 \mathrm{~m}$. The mean water depth is ca. $4 \mathrm{~m}$, and mean Secchi depth is ca. $2 \mathrm{~m}$ (Wang et al. unpubl. data). In the oligotrophic Liangzi Lake (Xie \& Yu 2003), macrophytes are dominated by vascular plants (primarily Potamogeton spp.) in open water. We sampled Liangzi Lake every month from 2002 to 2006. All submerged plants found at the sampling sites were carefully divided and identified to species level. Water depth at each sampling site was measured. The sites where the 3 charophyte species (Chara vulgaris L., C. braunii Gmelin and Nitella gracilens Morioka) occurred was chosen for further study; see Table 1 for the distributions of each species with depth at these sites.

C. vulgaris is a polymorphic charophyte with a broad, worldwide distribution between $70^{\circ} \mathrm{N}$ and $50^{\circ} \mathrm{S}$. It is found on all continents (Wood \& Imahori 1965) and is widely distributed in China (Han \& Li 1994). It can be found in both streams and still water bodies (White 1990). C. braunii has a cosmopolitan 
distribution (Wood \& Imahori 1959), and is widely distributed in China (Han \& Li 1994). This species can be found in the shallow water of oligotrophic lakes and prefers sandy substrates (Dubay \& Simmons 1981, Vieira \& Necchi 2003). Because of decreased water quality, $C$. braunii has disappeared from many European regions (Blindow 1994, SouliéMärsche \& Vautier 2004). N. gracilens is found only in East and Middle Asia as well as Africa. It is rare in China (Han \& Li 1994), and information about the ecological preferences of this species is not available. All 3 species are monoecious.

\section{Controlled water depth experiment}

The experiment was conducted from 28 March to 3 July 2006 in 3 outdoor ponds with the same area $(4 \times$ $4 \mathrm{~m})$ and depth $(4.5 \mathrm{~m})$ in the Liangzi Lake National Station of Lake Ecosystem $\left(30^{\circ} 05^{\prime}\right.$ to $30^{\circ} 18^{\prime} \mathrm{N}$, $114^{\circ} 21^{\prime}$ to $\left.114^{\circ} 39^{\prime} \mathrm{E}\right)$. These ponds were artificially constructed with cement and did not have natural sediment on the bottom. There were no differences in light attenuation when they were full of water. Considering the depth distribution of the 3 charophyte species in the field, we grew each species in a series of 3 different controlled depths, including shallow $(0.5$ and $1 \mathrm{~m})$, intermediate $(1.5 \mathrm{~m})$, and deep water $(2$ and $3 \mathrm{~m}$ ). A total of 90 plastic basins (diameter $=0.25 \mathrm{~m}$, height $=0.15 \mathrm{~m}$ ) containing $10 \mathrm{~cm}$ of sediment (total nitrogen $=2.94 \pm 0.02 \mathrm{mg} \mathrm{g}^{-1}$ dry weight [DW], total phosphorus $=0.128 \pm 0.002 \mathrm{mg} \mathrm{g}^{-1}$ DW, and total organic carbon $=12.9 \pm 0.3 \%$ ) were randomly suspended at the 5 defined depths by ropes in the 3 ponds with 6 basins at each water depth. A total of 10 germlings of each species that were similar in height and weight were placed in each pond such that 2 plants were placed at each water depth. Thus, every pond contained a total of 30 plants from 3 charophyte species. The germlings of each species were obtained from the germination of oospores harvested from healthy plants in June 2005. After transplanting, the ponds were filled with lake water. The concentrations of total nitrogen and total phosphorus of the lake water were $0.257 \pm 0.053 \mathrm{mg}$ $\mathrm{l}^{-1}(\mathrm{n}=3)$ and $0.015 \pm 0.002 \mathrm{mg} \mathrm{l}^{-1}(\mathrm{n}=3)$, respectively. The water level in the pond was checked and restored every $2 \mathrm{~d}$. During the experiment, the water in the pond was kept clean by the exchange of water every week, and all transplanted plants survived.

Every week, $\mathrm{pH}$, conductivity, turbidity, dissolved oxygen (DO), and water temperature in each pond were measured with a portable water quality ana- lyzer (Horiba). Every 2 wk, PPFD at the sub-surface of the water and at $0.5 \mathrm{~m}$ depth was measured by a UWQ-4341 sensor and Li-1400 data logger (Li-Cor). Before the experiment, primary shoot length (the distance from rhizoid origin to the stem tip) of each individual germling was measured and the means of ash-free dry weight (AFDW) of 10 germlings of similar height and fresh weight were measured and considered the primary plant mass of each plant.

Every $2 \mathrm{wk}$, the basins were placed close to the water surface, and the emergence of oogonia and antheridia was observed and recorded. Additionally, the number of branch whorls was counted. After red antheridia were found, observations of reproductive structures were carried out every week. When harvesting, all plants were gently rinsed with tap water and divided into 3 portions (stem, rhizoid, and bulbils). Shoot elongation was calculated as relative elongation rate (RER, $\mathrm{cm} \mathrm{cm}^{-1} \mathrm{~d}^{-1}$ ) using the formula RER $=[\operatorname{Ln}($ shoot length harvested) $-\operatorname{Ln}$ (primary shoot length)] / growth time, and increase in weight was calculated as relative growth rate (RGR, $\mathrm{g} \mathrm{g}^{-1}$ AFDW d ${ }^{-1}$ ), which was calculated using the formula RGR $=[\operatorname{Ln}$ (plant mass harvested) - Ln(primary plant mass)] / growth time. Moreover, the following reproductive traits were measured: vegetative reproduction by PB in total DW and generative reproduction by the proportion of branch whorls containing gametangia (PG) or oospores (PO) in total branch whorls of the plant. PG indicates the occurrence of sexual reproduction and $\mathrm{PO}$ indicates the maturation of oospores. A total of 4 or 5 apices (length: 3 to $5 \mathrm{~cm}$ ) of $0.06 \mathrm{~g}$ of total fresh weight for each replicate were selected and extracted in $6 \mathrm{ml} \mathrm{N}, \mathrm{N}$-dimethylformamide (DMF) in order to determine pigment concentration (Wang et al. 2008). Therefore, the harvested plant did not significantly affect the total DW.

\section{Data analysis}

Mean values were calculated for the 2 plants that were incubated together in the same tank at different depths for all parameters, and $t$-tests and 2-way ANOVAs were performed with $n=3$. Before performing statistical analyses, all data were tested for homogeneity of variances. Two-way ANOVAs were used to determine the interaction of water depth and species with regard to these parameters, and percentage of explained variance was based on a 2-way ANOVA that examined the effect of water depth as well as species. All tests were performed using SPSS 13.0 for Windows (SPSS). 


\section{RESULTS}

\section{Distribution of 3 charophyte species in Liangzi Lake}

Charophytes either exhibited patchy distributions near the lake shore or were interspersed with vascular plants (mainly Potamogeton maackianus A. Benn and $P$. crispus L.) in open water. Nitella gracilens occurred as a single species at all sites without other macrophytes. Chara braunii occurred at some sites in shallow water ( 0.5 to $1 \mathrm{~m}$ ) in which C. vulgaris was also occasionally found. However, the percentage of $C$. vulgaris to total biomass of charophyte plants was $<10 \%$. C. vulgaris flourished at depths of 1.5 to $2 \mathrm{~m}$, but were also interspersed with vascular plants in deep water $(2$ to $3 \mathrm{~m}$ ). Alternatively, $C$. braunii flourished at 1 to $1.5 \mathrm{~m}$ and $N$. gracilens at 0.5 to $1.5 \mathrm{~m}$ (Table 1 ).

\section{Underwater light and water environment in controlled experiment}

PPFD on the water surface varied from 299 on rainy days to $1045 \mu \mathrm{mol} \mathrm{m} \mathrm{m}^{-2} \mathrm{~s}^{-1}$ on cloudless sunny days during the experiment. Additionally, light intensity decreased from $564 \pm 16.6 \mu \mathrm{mol} \mathrm{m} \mathrm{m}^{-2} \mathrm{~s}^{-1}$ (mean $\pm \mathrm{SE}$ ) at $0.5 \mathrm{~m}$ to $33 \pm 4.6 \mu \mathrm{mol} \mathrm{m} \mathrm{m}^{-2}$ $\mathrm{s}^{-1}$ at $3 \mathrm{~m}$ (Fig. 1). For the parameters temperature, $\mathrm{pH}$, conductivity, and DO, no significant variation was found among depths with the exception of temperature, which varied by almost $2^{\circ} \mathrm{C}(\mathrm{p}<0.01)$ (Table 2).

\section{Shoot elongation and RGR}

All species exhibited convergent, dense branches in shallow water and extended their stems in response to increasing water depth. However, shoot elongation of the 2 Chara species was similar in shallow water $(0.5$ to $1 \mathrm{~m})$ but significantly different in intermediate water, both of which differed from $N$. gracilens except at $1 \mathrm{~m}$ depth (Fig. 2). Significant variation in the increase in weight based on AFDW was found among different water depths and species.
Table 1. Species composition of charophyte assemblages at Liangzi Lake, percent of biomass for each species and water depth of the sampling sites. Date are mean $\pm \mathrm{SE}, \mathrm{n}=6$

\begin{tabular}{|lrr|}
\hline Species composition & \% biomass & $\begin{array}{c}\text { Water } \\
\text { depth }(\mathrm{m})\end{array}$ \\
\hline Chara vulgaris & 100 & $1.7 \pm 0.4$ \\
C. vulgaris + Potamogeton & C. vulgaris: $5( \pm 2)+$ & $2.5 \pm 0.5$ \\
Crispus & P. crispus: $90( \pm 8)$ & \\
C. vulgaris + P. maackianus & C. vulgaris: $15( \pm 5)+$ & $2.0 \pm 0.6$ \\
C. vulgaris + C. braunii & P. maackianus: $85( \pm 5)$ & $0.8 \pm 0.2$ \\
Nitella gracilens & C. vulgaris: $5( \pm 2)+$ & $1.1 \pm 0.5$ \\
\hline
\end{tabular}

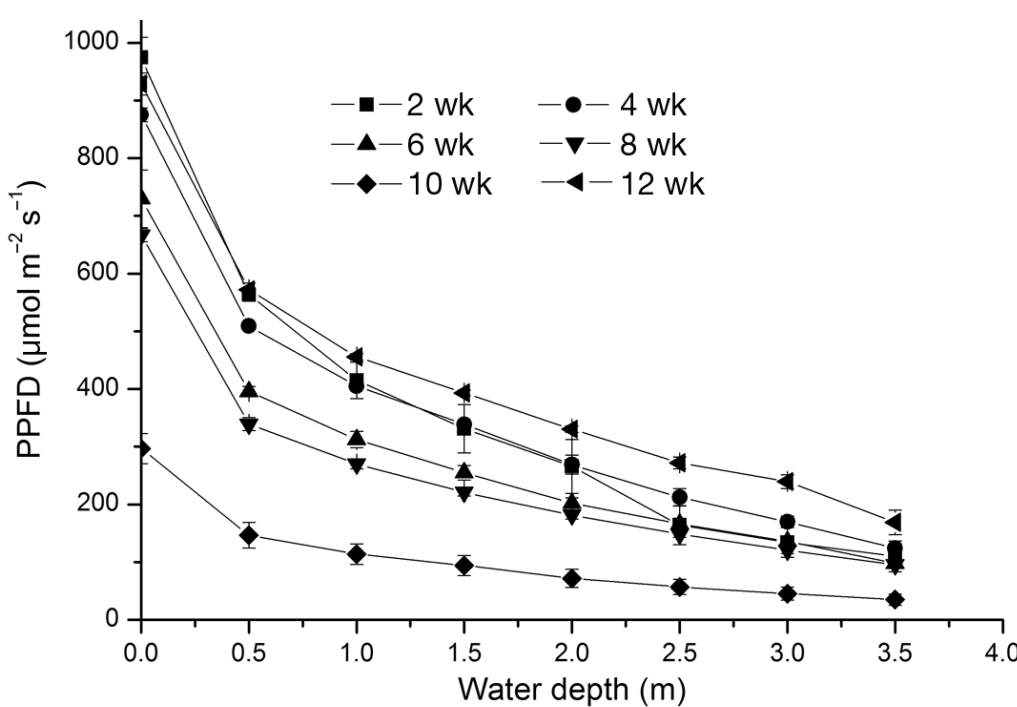

Fig. 1. Mean $( \pm \mathrm{SE})$ variation in photosynthetic photon flux density (PPFD) at the water surface and at different depths at $2 \mathrm{wk}$ intervals during the growth experiment $(\mathrm{n}=3)$

Table 2. Mean $( \pm \mathrm{SE}, \mathrm{n}=3$ ) environmental parameters (temperature, $\mathrm{pH}$, conductivity and dissolved oxygen [DO]) at different water depths

\begin{tabular}{|lcccc|}
\hline $\begin{array}{l}\text { Depth } \\
(\mathrm{m})\end{array}$ & $\begin{array}{c}\text { Temperature } \\
\left({ }^{\circ} \mathrm{C}\right)\end{array}$ & $\mathrm{pH}$ & $\begin{array}{c}\text { Conductivity } \\
\left(\mathrm{ms} \mathrm{cm}^{-1}\right)\end{array}$ & $\begin{array}{c}\mathrm{DO} \\
\left(\mathrm{mg} \mathrm{l}^{-1}\right)\end{array}$ \\
\hline 0 & $25.1 \pm 1.1$ & $7.71 \pm 0.21$ & $0.176 \pm 0.002$ & $6.94 \pm 0.25$ \\
0.5 & $24.8 \pm 1.3$ & $7.70 \pm 0.20$ & $0.175 \pm 0.002$ & $6.80 \pm 0.21$ \\
1 & $24.6 \pm 1.5$ & $7.68 \pm 0.19$ & $0.175 \pm 0.001$ & $6.68 \pm 0.20$ \\
1.5 & $24.4 \pm 1.3$ & $7.67 \pm 0.17$ & $0.174 \pm 0.001$ & $6.60 \pm 0.25$ \\
2 & $24.0 \pm 1.6$ & $7.65 \pm 0.16$ & $0.173 \pm 0.002$ & $6.53 \pm 0.25$ \\
3 & $23.1 \pm 2.0$ & $7.64 \pm 0.21$ & $0.172 \pm 0.001$ & $6.47 \pm 0.23$ \\
\hline
\end{tabular}

Higher RGR was found in deep water (3 m) for C. vulgaris and in shallow water $(0.5$ and $1 \mathrm{~m}$ ) for $C$. braunii.

The increase in weight of $N$. gracilens increased with the water depth at the $0.5-2.0 \mathrm{~m}$ range then decreased at $3 \mathrm{~m}$ (Fig. 3). A 2-way ANOVA revealed 


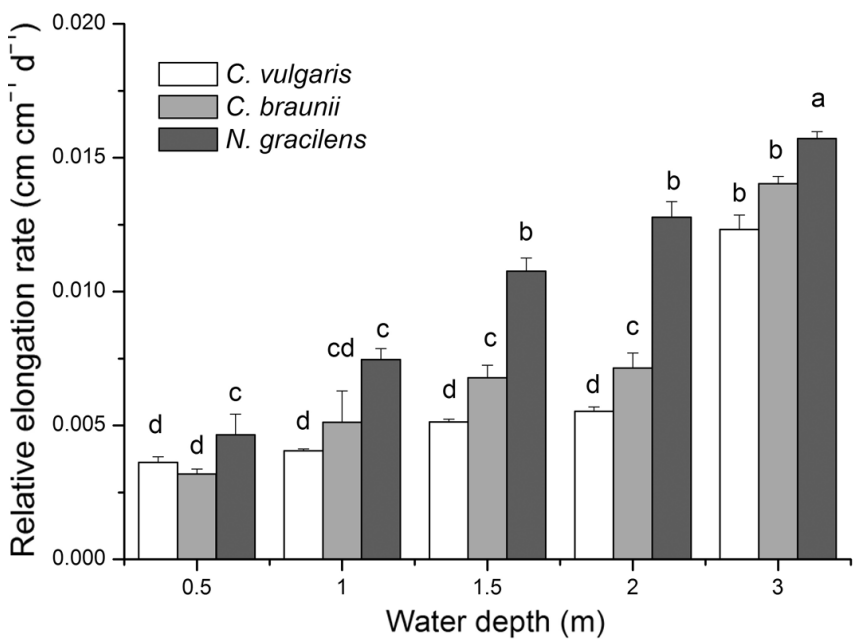

Fig. 2. Relative elongation rate (mean $\pm \mathrm{SE}, \mathrm{n}=3$ ) of the 3 charophyte species (Chara vulgaris, C. braunii and Nitella gracilens) in 5 different water depths. Different letters indicate significant differences $(p<0.05)$ among 15 different treatments

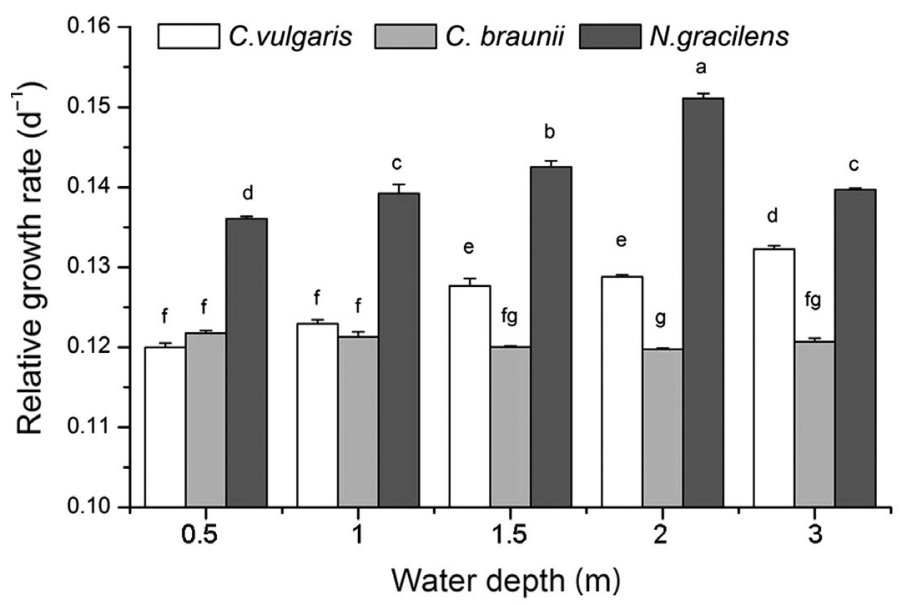

Fig. 3. Relative growth rate (mean $\pm \mathrm{SE}, \mathrm{n}=3$ ) based on ashfree dry weight (AFDW) of the 3 charophyte species (Chara vulgaris, C. braunii and Nitella gracilens) in 5 different water depths. Different letters indicate significant differences $(p<0.05)$ among 15 different treatments

that both water depth and species had a significant effect on shoot elongation and increase in weight. However, water depth contributed more than differences among species to the variance in shoot elongation, and less to the variation in the increases in weight (Table 3).

\section{Vegetative and sexual reproduction}

PB varied significantly with depth and species. The 2 Chara species showed a similar, biphasic response
Table 3. Percentage of explained variance based on 2-way ANOVA of water depth and species for relative elongation rate (RER), relative growth rate (RGR) based on ash-free dry weight (AFDW) of plants, proportion of bulbils in total AFDW (PB), proportion of branch containing gametangia in the 9th week (PG), branch containing oospores in the 13th week (PO), and ratios of chlorophyll $a$ to $b(\mathrm{chl} a / \mathrm{chl} b$ ) and chl $a$ to carotenoids (chl a/caro) in the plant apex. ${ }^{*} \mathrm{p}<$ $0.05 ;{ }^{* *} \mathrm{p}<0.01 ;{ }^{* * *} \mathrm{p}<0.001$

\begin{tabular}{|lcccc|}
\hline Parameters & $\begin{array}{c}\text { Water depth } \\
(\mathrm{W})\end{array}$ & $\begin{array}{c}\text { Species } \\
(\mathrm{S})\end{array}$ & $\mathrm{W} \times \mathrm{S}$ & Error \\
\hline RER & $69^{* * *}$ & $19^{* * *}$ & $5^{* * *}$ & 7 \\
RGR & $7^{* * *}$ & $82^{* * *}$ & $9^{* * *}$ & 2 \\
PB & $34^{* * *}$ & $31^{* * *}$ & $31^{* * *}$ & 4 \\
PG & $38^{* * *}$ & $55^{* * *}$ & $5^{* * *}$ & 2 \\
PO & $38^{* * *}$ & $51^{* * *}$ & $9^{* * *}$ & 2 \\
Chl a/chl $b$ & $5^{*}$ & $60^{* * *}$ & $10^{* * *}$ & 25 \\
Chl a/caro & $46^{* * *}$ & $30^{* * *}$ & $17^{* * *}$ & 7 \\
\hline
\end{tabular}

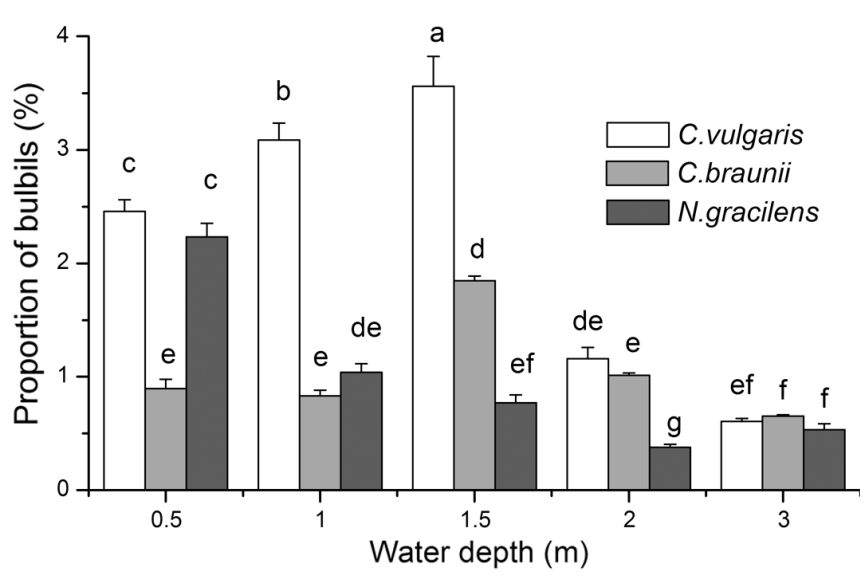

Fig. 4. Mean $( \pm \mathrm{SE}, \mathrm{n}=3$ ) proportions of bulbils by total ashfree dry weight (PB) of 3 charophyte species (Chara vulgaris, C. braunii and Nitella gracilens) in 5 different water depths. Different letters indicate significant differences $(p<0.05)$ among 15 different treatments

in $\mathrm{PB}$; that is, $\mathrm{PB}$ increased with water depth at the 0.5 to $1.5 \mathrm{~m}$ range then decreased at the 1.5 to $3 \mathrm{~m}$ range. PB of $N$. gracilens decreased until the water depth reached $2 \mathrm{~m}$, when the trend reversed (Fig. 4). A 2way ANOVA showed that water depth and species significantly interacted to affect $\mathrm{PB}$, with both factors contributing almost equally to the variance in $\mathrm{PB}$ (Table 3). Red antheridia of the 2 Chara species were simultaneously found on the apices of the plants at 3 water depths $(0.5,1$, and $1.5 \mathrm{~m})$ at Week 5 , and there was no significant difference of proportion of branch whorls containing gametangia among these 3 water depths. Black oospores were found $1 \mathrm{wk}$ later, which indicated the maturation of oospores. At the other 2 water depths (2 and $3 \mathrm{~m}$ ), the occurrence of gametangia and the maturation of oospores were prolonged 

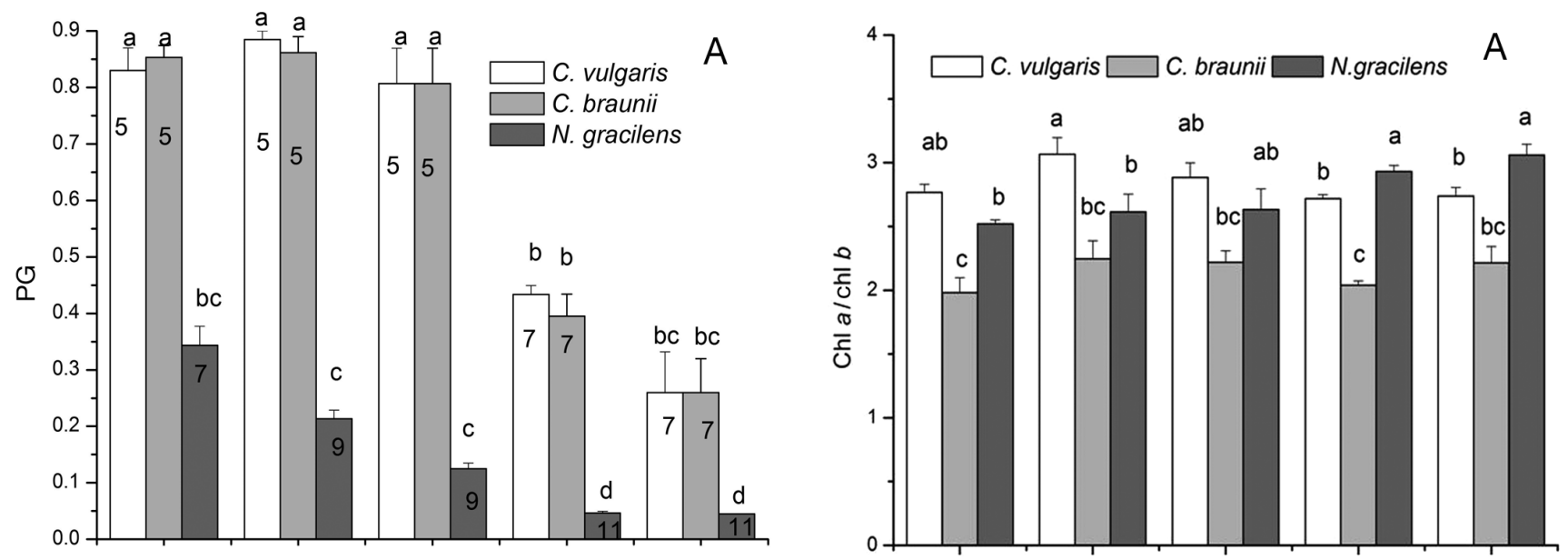

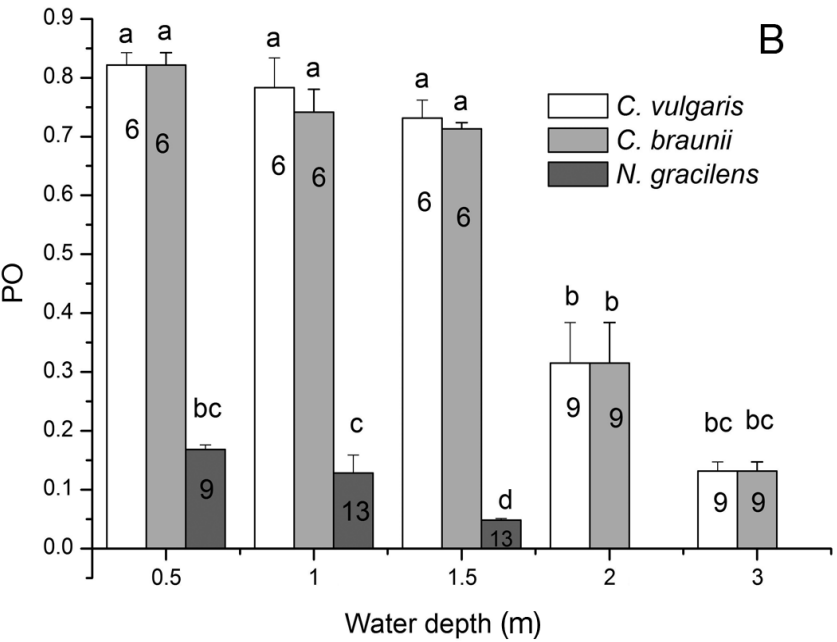

Fig. 5. Mean $( \pm \mathrm{SE}, \mathrm{n}=3)$ proportions of branch whorls containing (A) gametangia (PG) and (B) oospores (PO) in the total branch whorls of the whole plant for 3 charophyte species (Chara vulgaris, C. braunii and Nitella gracilens) in 5 different water depths. Numbers represent the week of first observation of gametangia and oospores; different letters indicate significant differences $(p<0.05)$ among 15 different treatments

for 2 and $3 \mathrm{wk}$, respectively. The proportion of branch whorls that contained gametangia or oospores decreased in deep water (2 and $3 \mathrm{~m}$ ) (Fig. 5). For $N$. gracilens, the first occurrence of gametangia was 2 wk later in shallow water $(0.5 \mathrm{~m})$, and 4 wk later in other depths than observed with the 2 Chara species. The maturation of oospores of $N$. gracilens was prolonged for $3 \mathrm{wk}$ in shallow water $(0.5 \mathrm{~m})$ and $7 \mathrm{wk}$ in moderate water depths (1 and $1.5 \mathrm{~m})$. No oospores were found in deep water. For $N$. gracilens, water depth significantly decreased PG and PO (Fig. 5). A 2way ANOVA revealed that variation among species contributed more than water depth to the variance in sexual reproduction (Table 3).

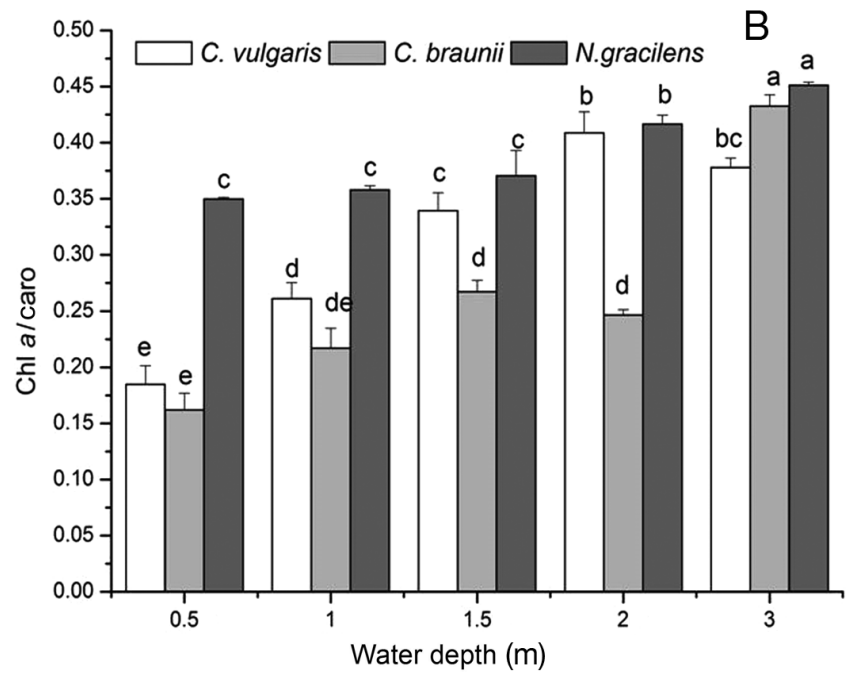

Fig. 6. Mean $( \pm \mathrm{SD}, \mathrm{n}=3$ ) (A) chlorophyll $a$ to $b(\mathrm{chl} a / \mathrm{chl} b)$ and (B) chl a to carotenoid (chl a/caro) ratios of 3 charophyte species (Chara vulgaris, C. braunii and Nitella gracilens) in 5 different water depths. Different letters indicate significant differences $(p<0.05)$ among 15 different treatments

\section{Pigment pattern}

For $C$. vulgaris, the chlorophyll $a$ to $b$ ratio $(\mathrm{chl} a /$ $\mathrm{chl} b$ ) was highest at $1 \mathrm{~m}$, significantly decreased at $2 \mathrm{~m}(\mathrm{p}<0.01)$, and slightly rebounded at $3 \mathrm{~m}$ (Fig. 6A). For $N$. gracilens, no significant variation in the chl a/ $\mathrm{chl} b$ ratio was found among $0.5,1$, and $1.5 \mathrm{~m}$, while there was a significant increase from 1.5 to $3 \mathrm{~m}(\mathrm{p}<$ 0.01). For $C$. braunii, no significant variation in the $\mathrm{chl} a / \mathrm{chl} b$ ratio was found among all depths. The chl $a$ to carotenoid (caro) ratio (chl a/caro) of both C. vulgaris and $C$. braunii increased with increasing water depth. For $N$. gracilens, no significant difference in the chl a/caro ratio existed among $0.5,1$, and $1.5 \mathrm{~m}$, while higher chl a/caro ratios were found in deep water (2 and $3 \mathrm{~m}$ ) (Fig. 6B). 


\section{DISCUSSION}

The 3 charophyte species did not occur as predicted along the depth gradient within Liangzi Lake (Table 1). This is not consistent with previous studies that have been carried out in oligotrophic deep-water lakes dominated by charophytes (e.g. Schwarz \& Hawes 1997). In shallow lakes, the depth distribution of charophyte species is mainly affected by photosynthetically active radiation, UV radiation and wave action (Asaeda et al. 2007); however, biotic factors such as grazing may also affect the depth distribution of charophytes in the field (Proctor 1999, Schwarz et al. 2002). Therefore, the outdoor experiment at controlled depths only partly explains the distribution of charophyte species in the lake.

\section{Morphological plasticity and pigment patterns}

Morphological plasticity of charophytes in response to varying water depths is usually achieved by elongation of the shoot (e.g. Asaeda et al. 2007). In this study, increased shoot elongation with increasing water depth (Fig. 2) for 3 charophyte species is consistent with the results reported by Asaeda et al. (2007). Additionally, the inter-species differences in shoot elongation that existed between the 2 Chara species and Nitella gracilens were mainly affected by water depth (Table 3). This indicates that the inter-species differences in the responses to depth of these charophytes reflect distinct, species-specific demands for light for photosynthesis (Schwarz et al. 1996, 2002) and explains their distinct distribution in the water column.

Charophytes exhibit a specific pattern of vegetative growth that originates from stem nodes - developing branches and extending transversally in response to an increase of underwater light intensity (Andrews et al. 1984a) or a decrease in water level (Casanova 1994). This results from light-induced inhibition of cell elongation, causing reduced shoot elongation in high light or shallow water. In the present study, the weight of both Chara vulgaris and $N$. gracilens increased with water depth (Figs. 1 \& 3). Considering the high light intensity in shallow water, we reasoned that the reduced weight increases of $C$. vulgaris and $N$. gracilens in shallow water may have resulted from high light stress, leading to photoinhibition. Convergent and steeply upward pointing branches of the plants that were found in shallow water may be a mechanism to protect the plant from damage by high light intensity (Schneider et al. 2006, Wang et al. 2008).
A decrease of the chl $a / \mathrm{chl} b$ ratio has been regarded as an adaptation to decreased irradiance for some charophyte species (e.g. Chara hispida, C. corallina, C. aspera and C. vulgaris; Andrews et al. 1984b, Howard-Williams et al. 1995, Blindow et al. 2003, Wang et al. 2008). In this experiment, the decreased $\mathrm{chl} a / \mathrm{chl} b$ ratios of $C$. vulgaris that were found between 1 and $2 \mathrm{~m}$ depth confirm this notion. However, the variation in the $\mathrm{chl} a / \mathrm{chl} b$ ratio of charophyte plants with water depth may not be directly correlated with changed light intensity. Increasing water depth usually leads to not only a change in light intensity but also diversification of the light spectrum (Stross et al. 1988, 1995), which correspondingly affects pigment content (Czeczuga 1986). In addition, not all charophyte species alter their $\mathrm{chl} a / \mathrm{chl} b$ ratio in response to the changes of light in the environment. For example, no significant difference in the $\mathrm{chl} a / \mathrm{chl} b$ ratio was found among varied light intensities in Chara canescens (Küster et al. 2004) and C. intermedia Braun (Schneider et al. 2006). In the present study, the $\mathrm{chl} a / \mathrm{chl} b$ ratio of $C$. braunii did not significantly vary with increasing depth. This may indicate that $C$. braunii, like C. canescens and C. intermedia, does not alter its chl $a / c h l ~ b$ ratio in response to variation in water depth. Additionally, although the chl a content of $N$. gracilens increased with the increase of water depth in this study, chl $b$ content did not vary significantly. Therefore, $N$. gracilens showed a higher chl $a / \mathrm{chl} b$ ratio in deep water $(3 \mathrm{~m})$ compared with that in shallow water $(0.5 \mathrm{~m})$. This indicates that chl $a$, rather than chl $b$, could be a more critical pigment for $N$. gracilens in response to low light conditions. A similar result was found for C. globularis in response to extremely low light conditions (Schagerl \& Pichler 2000).

Since carotenes protect plants from excessive light intensity, the chl a/caro ratio has been postulated to be related to the light-protecting capacity of plants (Küster et al. 2000, 2004, 2005, Schagerl \& Pichler 2000, Schneider et al. 2006, Wang et al. 2008). In the present study, although the chl a/caro ratio varied significantly among species, the lower chl a/caro ratio of the 3 charophyte species in shallow waters may indicate enhanced light protection at high light intensities for each species. Convergent and dense branches of plants and reduced shoot elongation in shallow water (Fig. 2) indicate similar functions.

\section{Vegetative and sexual reproduction}

In general, the presence of bulbils is interpreted as a build-up of the photosynthetic resources (starch) 
and usually observed (with PB > 10\%) in warmer months (Casanova 1994). In the present study, $N$. gracilens responded to increased water depth by decreasing PB (Fig. 4). This indicates that photosynthesis and resultant bulbil production of $N$. gracilens increased with increasing light intensity. In contrast to $N$. gracilens, the 2 Chara species had the highest $\mathrm{PB}$ at the intermediate depth $(1.5 \mathrm{~m})$. According to Vieira \& Necchi (2003), light saturation $\left(l_{\mathrm{S}}\right)$ for $C$. braunii was only $136 \mu \mathrm{mol}$ photons $\mathrm{m}^{-2} \mathrm{~s}^{-1}$ under the highest light condition of $1225 \mu \mathrm{mol}$ photons $\mathrm{m}^{-2} \mathrm{~s}^{-1}$. Considering the much higher growth light intensity than $l_{\mathrm{s}}$, we ascribe the lower PB of both Chara species in shallow water $(0.5 \mathrm{~m})$ to photo-inhibition, since PB depends on light intensity for photosynthesis as well as traits that are related to photo-inhibition (Asaeda et al. 2007). Furthermore, photo-inhibition has been shown to be indirectly associated with a lower chl a/ caro ratio in shallow water than in deep water. The 2 Chara species extended their shoots and developed their bulbils in response to the increase of water depth (from 0.5 to $1.5 \mathrm{~m}$ ). However, deeper water (2 and $3 \mathrm{~m}$ ) led to elongated shoots and decreased PBs. This indicates that more resources may be allocated to stem growth toward the water surface, which correlates with decreased investment in vegetative reproduction in deep water. Similar results were found in other macrophytes, including emergent Scirpus maritimus var. paludosus (Lieffers \& Shay 1981) and Phragmites australis (Vretare et al. 2001), floatingleaved Nymphoides peltata (Xiao et. al. 2006), and submerged Myriophyllum spicatum (Strand \& Weisner 2001). This conforms to the relevant strategy of energy and biomass allocation for plants under poor light conditions (e.g. Barko \& Smart 1981).

Both the emergence of gametangia and maturation of oospores of the 3 charophyte species were delayed at increasing water depths. This confirms the previous conclusion that decreasing water levels stimulates the occurrence of sexual reproduction and maturation of oospores, while increasing water levels prolongs sexual reproduction (Casanova \& Brock 1999b, Bonis \& Grillas 2002). The stimulation of sexual reproduction by decreasing water levels is thought to be due to increased light availability (Bonis \& Grillas 2002, Wang et al. 2008). However, possible effects of temperature on the occurrence of gametangia cannot be ignored (Guerlesquin 1990, Simčič \& Germ 2010), and temperature might be a more important determinant that light intensity for the maturation of oospores $(\mathrm{H}$. Wang et al. unpul. data). Our analysis revealed that differences among species contributed more to the variance in timing of sexual reproduction than did water depth (Table 3). We argue that these differences in sexual reproduction reflect the respective reproductive strategies of the 3 charophyte species.

For C. vulgaris and N. gracilens, low RER and RGR, as well as high PB and high PG and PO were found in shallow water. We considered that the occurrences of both vegetative and sexual reproduction in shallow water were at the expense of increases in weight. Additionally, the reduced PG and PO as well as increased shoot elongation with increasing water depth also confirmed the assumption that these 3 charophyte species extend their shoots at the expense of sexual reproduction in deep water. Similar results have been found in other charophyte species (Casanova 1994, Casanova \& Brock 1999a, Asaeda et al. 2007).

In shallow water, $C$. vulgaris and $N$. gracilens suffered light stress and developed their bulbils and sexual structures at the expense of weight. In deep water, the 3 charophyte species extended their shoots at the expense of vegetative and sexual reproduction. This reflects the difference of these 3 charophyte species in allocation patterns among depth levels.

\section{CONCLUSIONS}

The 3 charophyte species we studied exhibited different patterns of resource allocation along a depth gradient. In deep water, charophyte plants extended their stems at the expense of vegetative and sexual reproduction. In total, differences among species contributed more than water depth to the observed variance in sexual production, which reflects differences in reproductive strategies among species.

Acknowledgements. We are extremely grateful to Dr. Shujun Liu for help with the experiment. We also thank Dr. JinYang for improving the English of the manuscript. This research was financially supported by the Special Foundation of National Science and Technology Basic Research (2013FY112300), the previous Research Project of '973' Program (2014CB460601) and the National Natural Science Foundation of China (31000161 and 51209190).

\section{LITERATURE CITED}

Andrews M, Box R, McInroy S, Raven JA (1984a) Growth of Chara hispida II. Shade adaptation. J Ecol 72:885-895

Andrews M, Davison IR, Andrews ME, Raven JA (1984b) Growth of Chara hispida: I. Apical growth and basal decay. J Ecol 72:873-884

Asaeda T, Rajapakse L, Sanderson B (2007) Morphological and reproductive acclimations to growth of two charo- 
phyte species in shallow and deep water. Aquat Bot 86: 393-401

> Barko JW, Smart RM (1981) Comparative influences of light and temperature on the growth and metabolism of selected submersed freshwater macrophytes. Ecol Monogr 51:219-235

Blindow I (1994) Rare and threatened charophytes in Sweden. Sven Bot Tidskr 88:65-73

Blindow I, Schütte M (2007) Elongation and mat formation of Chara aspera under different light and salinity conditions. Hydrobiologia 584:69-76

Blindow I, Dietrich J, Möllmann N, Schubert H (2003) Growth, photosynthesis and fertility of Chara aspera under different light and salinity conditions. Aquat Bot 76:213-234

Bonis A, Grillas P (2002) Deposition, germination and spatiotemporal patterns of charophyte propagule banks: a review. Aquat Bot 72:235-248

Casanova MT (1994) Vegetative and reproductive responses of charophytes to water-level fluctuations in permanent and temporary wetlands in Australia. Aust J Mar Freshw Res 45:1409-1419

> Casanova MT, Brock MA (1999a) Charophyte occurrence, seed banks and establishment in farm dams in New South Wales. Aust J Bot 47:437-444

Casanova MT, Brock MA (1999b) Life histories of charophytes from permanent and temporary wetlands in eastern Australia. Aust J Bot 47:383-397

Chambers PA, Kalff J (1987a) Light and nutrients in the control of aquatic plant community structure. I. In situ experiments. J Ecol 75:611-619

Chambers PA, Kalff J (1987b) Light and nutrients in the control of aquatic plant community structure. II. In situ observations. J Ecol 75:621-628

Coops H, van den Brink FWB, van der Velde G (1996) Growth and morphological responses of four helophyte species in an experimental water-depth gradient. Aquat Bot 54:11-24

Czeczuga B (1986) The effect of light on the content of photosynthetically active pigments in species of the genus Chara. Aquat Bot 24:397-401

de Bakker N, van Beem A, van de Staaij J, Rozema J, Aerts R (2001) Effects of UV-B radiation on a charophycean alga, Chara aspera. Plant Ecol 154:237-246

Deegan BM, White SD, Ganf GG (2007) The influence of water level fluctuations on the growth of four emergent macrophyte species. Aquat Bot 86:309-315

Dubay CE, Simmons GM Jr (1981) Distribution and composition of the macrophyte community in Mountain Lake, Virginia. Va J Sci 32:17-22

Guerlesquin M (1990) Contribution to morphogenesis and sexual reproduction in Charophyta. Phytomorphology 40:189-216

Han FS, Li YY (1994) Charophyta. In: Flora algarum sinicarum aquae dulcis, Tomus 3. Science Press, Beijing (in Chinese)

Howard-Williams C, Schwarz AM, Vincent WF (1995) Deepwater aquatic plant communities in an oligotrophic lake: physiological responses to variable light. Freshw Biol 33: 91-102

> Küster A, Schaible R, Schubert H (2000) Light acclimation of the charophyte Lamprothamnium papulosum. Aquat Bot 68:205-216

Küster A, Schaible R, Schubert H (2004) Light acclimation of photosynthesis in three charophyte species. Aquat Bot
79:111-124

> Küster A, Schaible R, Schubert H (2005) Sex-specific light acclimation of Chara canescens (Charophyta). Aquat Bot 83:129-140

- Lieffers V, Shay J (1981) The effects of water level on the growth and reproduction of Scirpus maritimus var. paludosus. Can J Bot 59:118-121

Proctor VW (1999) Charophytivory, playas y papalotes, a local paradigm of global relevance. Aust J Bot 47: 399-406

Schagerl M, Pichler C (2000) Pigment composition of freshwater Charophyceae. Aquat Bot 67:117-129

Schneider S, Ziegler C, Melzer A (2006) Growth towards light as an adaptation to high light conditions in Chara branches. New Phytol 172:83-91

Schneider SC, Pichler DE, Andersen T, Melzer A (2015) Light acclimation in submerged macrophytes: the role of plant elongation, pigmentation and branch orientation differ among Chara species. Aquat Bot 120:121-128

Schwarz AM, Hawes II, Howard-Williams C (1996) The role of photosynthesis/light relationship in determining lower depth limits of Characeae in South Island, New Zealand lakes. Freshw Biol 35:69-80

Schwarz AM, Hawes I (1997) Effects of changing water clarity on characean biomass and species composition in a large oligotrophic lake. Aquat Bot 56:169-181

Schwarz AM, de Winton M, Hawes I (2002) Species-specific depth zonation in New Zealand charophytes as a function of light availability. Aquat Bot 72:209-217

Simčič T, Germ M (2010) Increased temperature due to global warming alters the respiratory potential in aquatic organisms from an oligotrophic lake. Int Rev Hydrobiol 95:370-382

Sorrell BK, Hawes I, Schwarz AM, Sutherland D (2001) Inter-specific differences in photosynthetic carbon uptake, photosynthate partitioning and extracellular organic carbon release by deep-water characean algae. Freshw Biol 46:453-464

Soulié-Märsche I, Vautier J (2004) Ecology and life cycle of Chara braunii (Charales) in a Mediterranean habitat. Vie Milieu 54:37-45 (in French, with English Abstract)

Spence DHN (1976) Light and plant response in fresh water. In: Evans GC, Bainbridge R, Rackham O (eds) Light as an ecological factor. Blackwell Scientific Publications, Oxford, p 93-133

Spence DHN (1982) The zonation of plants in freshwater lakes. Adv Ecol Res 12:37-125

Spence DHN, Chrystal J (1970) Photosynthesis and zonation of freshwater macrophytes. II. Adaptability of species of deep and shallow water. New Phytol 69:127-227

Steinman AD, Havens KE, Rodusky AJ, Sharfstein B, James RT, Harwell MC (2002) The influence of environmental variables and a managed water recession on the growth of charophytes in a large, subtropical lake. Aquat Bot 72: 297-313

> Strand JA, Weisner SEB (2001) Morphological plastic responses to water depth and wave exposure in an aquatic plant (Myriophyllum spicatum). J Ecol 89: $166-175$

> Stross R, Huvane J, Sokol R (1988) Internal structure of deep dwelling Nitella meandows. Aquat Bot 29:329-345

Stross R, Sokol R, Schwarz AM, Howard-Williams C (1995) Lake optics and depth limits for photogenesis and photosynthesis in charophyte meadows. Hydrobiologia 302: $11-19$ 
Vieira J Jr, Necchi O Jr (2003) Photosynthetic characteristics of charophytes from tropical lotic ecosystems. Phycol Res 51:51-60

Vretare V, Weisner S, Strand J, Graneli W (2001) Phenotypic plasticity in Phragmites australis as a functional response to water depth. Aquat Bot 69:127-145

> Wang H, Yu D, Xiao K (2008) The interactive effects of irradiance and photoperiod on Chara vulgaris L.: concerted responses in morphology, physiology, and reproduction. Hydrobiologia 610:33-41

White DS (1990) Biological relationships to convective flow patterns within stream beds. Hydrobiologia 196:149-158

Wood RD, Imahori K (1959) Geographical distribution of

Editorial responsibility: Alistair Poore,

Sydney, NSW, Australia
Characeae. J Torrey Bot Soc 86:172-183

Wood RD, Imahori K (1965) A revision of the Characeae, Vols 1 \& 2. Cramer, Weinheim

Xiao K, Yu D, Huang Y, Wang H (2006) Plastic and nonplastic variation in clonal morphology of Nymphoides peltata along a water depth gradient in Liangzi Lake, China. J Freshw Ecol 21:371-379

Xie Y, Yu D (2003) The significance of lateral roots in phosphorus (P) acquisition of water hyacinth (Eichhornia crassipes). Aquat Bot 75:311-321

Yu L, Yu D (2009) Responses of the threatened aquatic plant Ottelia alismoides to water level fluctuations. Fundam Appl Limnol 174:295-300

Submitted: July 24, 2014; Accepted: July 28, 2015

Proofs received from author(s): September 14, 2015 